\title{
A PERSONAGEM-TIPO NA REVISTA DE WALTER PINTO CONFIGURAÇÃO E DISSOLUÇÃO
}

\begin{abstract}
Nanci de Freitas (Uerj)
O texto apresenta reflexões sobre a tipificação no teatro de revista, uma das mais importantes convenções do gênero e sua presença na Companhia Walter Pinto (19391961). O foco da análise está nas personagens-tipo - o malandro, a mulata, o caipira, o português, o carioca e a mulher fatal - selecionadas nos textos das revistas de Walter Pinto, localizadas em acervo do Cedoc/Funarte. ${ }^{1}$

TEATRO DE REVISTA, COMPANHIA WALTER PINTO, PERSONAGENS-TIPO.
\end{abstract}

FREITAS, Nanci de. A personagem-tipo na revista de Walter Pinto: configuração e dissolução.Textos escolhidos de cultura e arte populares, Rio de Janeiro, v.12, n.1, p. 119-142, mai. 2015. 


\section{STOCK CHARACTERS IN WALTER PINTO'S MUSICAL THEATER \\ CONFIGURATION AND DISSOLUTION}

Nanci de Freitas (Uerj)

The text presents reflections on the characterization in musical theater, one of the most important conventions of the genre, and its presence in the Company Walter Pinto (1939-1961). The focus of the analysis are the stock characters - the "malandro" (hedonist), the mulatto woman, the hick, the Portuguese, the "carioca" (Rio citizen) and the "femme fatale" (female seductress) - in the texts of the "revistas" (vaudeville shows or variety shows) of Walter Pinto, in the Cedoc/Funarte document collection.

MUSICAL THEATER; WALTER PINTO COMPANY; STOCK CHARACTERS.

FREITAS, Nanci de. A personagem-tipo na revista de Walter Pinto: configuração e dissolução. Textos escolhidos de cultura e arte populares, Rio de Janeiro, v.12, n.1, p. 119-142, mai. 2015. 


\section{TEATRO DE REVISTA E COMICIDADE: RASTROS E FIGURAÇÕES}

A presença do ator no teatro de revista se dá por meio de figurações articuladas no vasto material que compõe a representação cênica nesse gênero teatral. Cenas cômicas se alternam com quadros de fantasia, nos quais alegorias carnavalescas e elementos grotescos se juntam em função da sátira social. Pelos atos de variedades desfilam tipos que representam máscaras sociais e caricaturas de personagens da atualidade. Números musicais com os mais diferentes ritmos, nacionais e estrangeiros, danças e performances cômicas se entrelaçam com cenas de plateia. Uma multiplicidade da presença humana inunda a cena da revista, sugerindo diversos modos de atuação.

Formas cênicas e textuais diversas aproximam o teatro de revista de tradições da comicidade e de gêneros como a commedia dell'arte, a comédia de costumes, o vaudeville, o melodrama, a opereta, as farsas e burletas francesas, entre outros que se afastam dos cânones dramatúrgicos. Os textos da revista não constituem unidade dramática nem incluem personagens dotadas de subjetividade; ao contrário, apresentam formas épicas de representação cênica por seu caráter narrativo e fragmentado. $O$ que se vê é a proliferação de tipos cômicos reconhecíveis pelo público como parte de um acervo comum de referências culturais. A caricatura aparece como forma de sátira social e política na alusão a personalidades da vida pública, como é o caso da presença constante do presidente Getúlio Vargas, nas revistas brasileiras das décadas de 1940 e 1950. As alegorias também são recursos amplamente utilizados, seja na citação de figuras míticas, literárias e históricas ou em analogias com determinados setores da vida social.

A tragédia grega teria surgido com o ditirambo, ritual em honra a Dioniso no qual se comemorava a abundância das colheitas. A mesma festa teria dado origem à comédia, os kômoi, nos quais jovens mascarados exibiam elementos profanos e disfarces de animais. Nas poucas referências à comédia na Arte Poéti$c a$, Aristóteles (s/d., p. 246) afirma: "a comédia é a imitação de maus costumes, não contudo de toda sorte de vícios, mas só daquela parte do ignominioso que é o ridículo. O ridículo reside num defeito e numa tara que não apresentam caráter doloroso ou corruptor. Tal é, por exemplo, o caso da máscara cômica feia e disforme, que não é causa de sofrimento".

As atividades de atores e duplas de comediantes, contudo, já ocorriam antes mesmo do apogeu do teatro grego, no século $\mathrm{V}$ a.C., mas teria sido durante o Império Romano que formas do teatro popular como a saturae lanx, os mimos e a farsa atellana, dramatizações enfatizadas por elementos fálicos, ganhariam notoriedade nas celebrações de casamentos, sendo incluídas nos jogos da cidade ou ludi (na língua inglesa, ludicrous: risível, burlesco) (GASSNER, 1991, p. 111). 
A atellana (da cidade de Atella) teria introduzido a tradição das máscaras representando determinados setores da vida social. Baccus e Maccus formavam uma dupla de glutões: Baccus era um camponês grosseiro, guloso e infeliz nas aventuras amorosas; Maccus era um tipo inchado e vermelho, fanfarrão e esperto, sempre se vangloriando de suas torpezas. Informa Ruggero Jacobi (I956, p. 22): "A saturae lanx, como o próprio nome indica, era, nada mais nada menos, um ato variado, com piadas, música, dança. Uma pequena revista (...) Quanto à farsa atellana, embora escrita, deixava larga margem à sátira política (...) e parece ter tido história linear rápida, de fácil compreensão." Plauto, o mais importante dos comediógrafos romanos, daria forma literária a essas máscaras, atribuindoIhes caracteres psicológicos e criando enredos ricos em intrigas e surpresas.

Dessas tradições populares de máscaras descende a commedia dell'arte italiana, construída sobre bases teatrais extraliterárias, em oposição ao teatro erudito da cultura renascentista. De modo geral, sua tipologia se caracterizava por figuras que atuavam na forma de dupla, como é o caso dos Zanni, criados miseráveis e cômicos, incluindo Arlequim, que compunha uma famosa dupla com Brighela e também com a Colombina. O Arlequim viria a ser a principal figura, incorporando em sua forma aspectos grotescos do diabo medieval.

\section{O TEATRO DE REVISTA NO BRASIL: ASSIMILAÇÕES, TIPOS E ACERVOS}

Segundo Neyde Veneziano (1991, p. 23), a revista teria surgido nos teatros de feira de Paris, por volta de 1715, como uma mistura de vaudeville e opereta, ganhando o nome de revue de fin d'année, por passar em revista os fatos marcantes do ano. Da França seguiria para outros países, sendo Portugal um dos primeiros a adotá-la, em 1851 .

A revista de Portugal desembarcou no Brasil na segunda metade do século XIX, legitimando-se com a dupla Arthur Azevedo e Moreira Sampaio, no Rio de Janeiro, a partir da estreia de $O$ mandarim, em 1884. O cruzamento da matriz do teatro musicado europeu com o temperamento irreverente da cena carioca, já configurada nas comédias de costumes de Martins Pena e França Júnior, oferecia terreno fértil para a assimilação da revista na cultura brasileira. Configuração que se une ao amplo acervo musical do país e do samba em especial.

Nos primeiros anos do século XX, o "teatro ligeiro" estava repleto de personagens que espelhavam os conflitos de uma realidade marcada pela presença de variadas raças:

Italianos, turcos, caipiras, portugueses, tipos sabe-tudo eram personagens dos espetáculos ligeiros e marcavam suas presenças 
pelo modo engraçado de falar, andar e agir. Como na commedia dell'arte, onde o bergamasco dos zanni, o latim do dottore ou o sotaque espanhol do capitano obtinham efeitos altamente risíveis, numa miscelânea de linguagem e variedade de ritmos de grande expressão cômica, também no Teatro de Revista Brasileiro a população representativa de uma sociedade pequeno-burguesa em ascensão inseria-se nesse modelo espirituoso. $E$, também como na commedia dell'arte, algumas destas máscaras sociais (como podem ser considerados os tipos) foram tornando obrigatórias suas presenças, transcendendo-se à categoria das personagens fixas da revista (VENEZIANO, 1991, p. 122).

Os tipos da revista foram adquirindo contornos em mescla da comédia de costumes com a narrativa dos acontecimentos, modificando-se a partir das ondulações sociais e das novas questões políticas que iam surgindo com a modernização da sociedade. Analisando as revistas de ano de Arthur Azevedo, Flora Süssekind (1986, p. 95) percebeu que as personagens raramente representam individualidades:

É, pois, fundamentalmente com personagens-tipo (o português, o carioca, o sábio, a mulher-fatal, o cidadão da capital, o homem do interior) que trabalha Artur Azevedo nas revistas de ano. E os utiliza de maneira bastante semelhante às generalizações que opera com nomes como "jagunço", "tribofe", "bilontra" ou "manequim". Os personagens, como as definições, a rigor parecem marcados por particularidades bem nítidas, mas apresentam contornos bastante elásticos e "universais" para que a plateia teatral do fim de século possa reconhecer neles elementos convencionais da revista.

Roberto DaMatta (1977) analisa a tipicidade na sociedade brasileira em um estudo do carnaval, visto como um sumário dessa sociedade, em que raças, credos, classes e ideologias comungariam pacificamente ao som do samba e da miscigenação racial. ${ }^{2} \mathrm{Na}$ festa carnavalesca haveria uma temporária neutralização das regras sociais e atividades estruturais cotidianas, instaurando-se um tempo liminar no qual as individualidades podem manter-se ocultas por trás das fantasias. Esses disfarces dariam projeção a tipos que sintetizam aspectos culturais reconhecíveis no âmbito da coletividade:

Em termos sociológicos, pode-se dizer que uma fantasia é uma máscara social conscientemente assumida e marcada por um sinal exterior visível, com frequência delimitada culturalmente e, de modo consequente, estereotipado. Deste modo o índio, o cowboy, o pirata e a baiana do carnaval reproduzem apenas parcialmente as atitudes e as vestes destes personagens. Não se trata de uma re- 
produção nos termos de uma homologia, mas de uma representação de alguns traços que a cultura brasileira define como sendo essenciais a uma criação de fantasia (ou de brincadeira) do tipo (DAMATTA, 1977, p.123).

De certo modo, a revista teatral traduzia esse espaço paradigmático de suspensão dos valores cotidianos, fazendo do palco lugar em que os comportamentos, os tipos sociais, as personalidades ilustres e as posições políticas se tornavam elementos carnavalizados e farsescos. Tradução de outro modo, já que aqui não se trata de uma festa como o carnaval e sim de um espetáculo e como tal exige códigos e convenções representacionais. As figuras desfilavam sem hierarquização, diante de um público que se encontrava numa espécie de celebração teatral. É bom lembrarmos que os palcos em que tais "celebrações" ocorriam localizavam-se na Praça Tiradentes, ponto estratégico do Centro da cidade, para onde convergiam moradores das mais diversas áreas.

A partir da década de 1920, a revista de ano perderia seu caráter de sátira ingênua delineada por um fio condutor temático, adquirindo a forma de um teatro de variedades, com números musicais apoteóticos e quadros de fantasia alegóricos. A influência da companhia francesa Bataclan introduziria o gênero féerie, temperando a revista com o luxo e a ênfase no corpo feminino.

No universo "carnavalizado" e satírico do teatro de revista, a tipificação foi, desde sempre, uma das convenções mais importantes. Apesar da crescente diluição dessa forma teatral, o tipo se manteve como marca, um recurso que permitia identificar prontamente o gênero, conquistar a simpatia do público e servir como ponto de partida para o trabalho do ator.

Este estudo propõe uma abordagem da personagem-tipo no teatro de revista da Companhia Walter Pinto, tendo como fontes de referência peças teatrais, recortes de jornais, fotografias e outros materiais selecionados em pesquisa realizada no Acervo Walter Pinto, localizado no Centro de Documentação da Funarte, no Rio de Janeiro.

\section{A TIPIFICAÇÃO NA REVISTA DE WALTER PINTO: TRADIÇÃO E MODERNIDADE}

A configuração da modernidade teatral no Brasil ocorreria na década de 1940, com a montagem de Vestido de noiva, de Nelson Rodrigues (direção do polonês Ziembinski e cenário de Santa Rosa). A iniciativa, realizada pelo grupo Os comediantes, desencadeou novas perspectivas artísticas nas décadas seguintes: os projetos, assimilando aspectos do teatro europeu, passaram a ser elaborados por encenadores e se propunham à criação de poéticas cênicas, integrando 
a equipe sob uma determinada proposta conceitual e autoral. O teatro moderno, visto como prática profissional, ganharia força em São Paulo, a partir de 1948, com as atividades do Teatro Brasileiro de Comédia - TBC, sob mecenato do industrial italiano Franco Zampari.

Essas práticas artísticas respondiam ao processo de modernização pelo qual passava a sociedade brasileira, principalmente após a Segunda Guerra Mundial, como explica Renato Ortiz (1988, p. 39):

A velha sociologia do desenvolvimento costumava descrever essas mudanças sublinhando fenômenos como o crescimento da industrialização e da urbanização, a transformação do sistema de estratificação social com a expansão da classe operária e das camadas médias, o advento da burocracia e das novas formas de controle gerencial, o aumento populacional, o desenvolvimento do setor terciário em detrimento do setor agrário. É dentro desse contexto mais amplo que são redefinidos os antigos meios (imprensa, rádio e cinema e direcionadas as técnicas como a televisão e o marketing. Sabemos que é nas grandes cidades que floresce este mundo moderno.

Na realidade do mercado teatral brasileiro, contudo, as tradições populares de bases oitocentistas continuavam em plena atividade durante os anos 40 . Esse "teatro antigo", sustentando-se nos pilares das convenções cênicas, cacoetes da improvisação e no "vedetismo" dos intérpretes, apresentava dificuldades de assimilação dos preceitos estéticos do "teatro de arte" e da dramaturgia moderna.

Em 1939, quando Walter Pinto herdou a Empresa de Teatro Pinto Ltda. de seu pai, Manuel Pinto, herdou também um tipo de revista em franca decadência. Percebendo os novos mecanismos introduzidos na sociedade pelos meios tecnológicos e cultura de massa, o empresário investiu em maquinaria, equipes técnicas e artísticas do Teatro Recreio, respeitando as convenções do gênero revista, mas imprimindo-lhe um ar de modernidade. Conseguiu criar sua marca teatral apostando na revitalização da revista féerie, conjugando beleza com humor malicioso, mulatas com coristas estrangeiras, tradições tipicamente brasileiras com a estética dos musicais americanos. O novo padrão de qualidade dos espetáculos, com mutações cenográficas monumentais, projeções cinematográficas, efeitos de luz e sombra, faria da revista um produto consumível por amplas faixas de público. Empreendendo certa moralização para afastar a censura, mas mantendo a malícia e o jogo de duplo sentido erótico, constituía um aparato espetacular concebido para agradar não apenas ao público masculino, mas também às muIheres e à família pequeno-burguesa. Desse modo, Walter Pinto conseguiu man- 
ter seu empreendimento até 1963, quando encerra as montagens. Afirma o diretor, em depoimento ao Serviço Nacional de Teatro - SNT: “Comecei a estudar a psicologia do público e a melhorar o elenco (...) quem vai ao teatro quer ver tudo bonito, cenário, roupa, mulheres. Teatro é uma ilusão. No teatro, um saco de aniagem com um jogo de luz pode parecer seda. Teatro é um sonho" (PINTO, 1961, p. 165-166).

Algumas convenções clássicas da revista se mantiveram na estrutura do teatro de Walter Pinto: cenas de comédia, números de plateia, performances diante da cortina, coreografias com bailarinos de ambos os sexos (boys and girls) e quadros de fantasia com cenários alegóricos que finalizavam em apoteose musical. E, claro, a tipificação.

De uma ampla galeria de tipos, que sofrem variações de acordo com a necessidade de enfoque e crônica do cotidiano, alguns permanecem na revista, seja por seu caráter popular ou por seu poder de representação. Neyde Veneziano (1991, p. 122) destaca quatro tipos principais: o malandro, a mulata, o caipira e o português.

\section{MALANDROS E MULATAS}

O "malandro" é um dos tipos mais populares do teatro de revista. Poderia ser aproximado, num horizonte arquetípico, com o zanni da commédia dell'arte, mais especificamente com o esperto Arlequim. Identificado como figura fora dos padrões vigentes de moralidade, o malandro consegue sempre "se dar bem" à custa do "jeitinho brasileiro". Ladrões, trapaceiros, espertos, gozadores, caloteiros, jogadores, mulherengos ou, como os chamava Artur Azevedo, jagunços, tribofes, bilontras, sempre esbanjaram alegria, na afirmação de um modo de vida marginal. Afirma Roberto DaMatta (1977, p. 154):

É na chamada "escola da vida" e na "escola de samba" (um equivalente simbólico da própria existência) que o malandro aprende o que se chama significativamente no Brasil de "arte da malandragem". A "malandragem" é, portanto, definida positivamente, assumindo a expressão - na maioria dos contextos em que é empregada - uma tonalidade de elogio, admiração e inveja. Ela revela, acima de tudo, a sabedoria de quem utiliza o sistema para seu próprio benefício, não sendo nunca uma "vítima das circunstâncias", como acontece com os Pierrot e os palhaços... Estando a um passo da marginalidade e a outro da estrutura, o malandro é o paradigma do tipo brasileiro do homem que é capaz de "vencer sem fazer força". 
O tipo alcançou seu apogeu durante o governo de Getúlio Vargas, com as performances de Oscarito, Grande Otelo e Zé Trindade. Na revista Acredite se quiser, encenada por Walter Pinto em 1940, o malandro aparece duplamente nas figuras de inveterados mulherengos, Pafúncio e Bartolo, que se encontram ocasionalmente em um cemitério, vestidos de preto. No quadro "Na cidade dos pés juntos", Bartolo, carregando um maço de flores, lamenta-se com o amigo, chorando a morte de sua mulher.

Bartolo: Desculpe Pafúncio, eu já nem sei o que digo. (outro tom). Mas agora reparo: você também está de luto? Acaso a Leonor.

Pafúncio: Não morreu, não. Minha mulher está boa.

Bartolo: Anh! Que susto! E esse luto que quer dizer?

Pafúncio: Chiu! Isto aqui é um truque meu. Estou aqui à espera de uma viuvinha que marcou encontro comigo às 4 horas.

Bartolo: Às 4 horas? ... Não é possível!...

Pafúncio: Por quê?

Bartolo: Não é possível, porque não creio que você tivesse a coragem de marcar um encontro em um lugar destes.

Pafúncio: Bobinho, é a melhor maneira. Eu de luto, ela também. Quem é que vai suspeitar que se trate de um namoro.

Bartolo: Mas isto é uma falta de respeito aos mortos!...Isto aqui é um santuário de saudades. Lágrimas, orações... Onde está a sua dignidade de homem casado?

Pafúncio: Está bem Bartolo. Não precisa ficar zangado. Vou embora. Pronto!... (Sai Pafúncio e entra Leonor)

Leonor: Bartolo, meu amor, eu me atrasei?

Bartolo: (que estava de costas, assusta-se e volta-se muito aflito) Depressa Leonor... Seu marido saiu daqui agora mesmo! (COSTA, FAISSAL, PINTO, 1940, s.p) ${ }^{3}$

Os dois tipos cômicos são enganadores e usam o mesmo artifício, a caracterização do luto, para praticar a arte da conquista. Na conta da esperteza da dupla de malandros, ganha Bartolo que, usando recursos histriônicos, engana o amigo Pafúncio, transformando-o em um grande palhaço.

Na peça de Walter Pinto, de 1950, Muié macho, sim sinhô, no quadro "Tiro e queda", localizamos outra dupla de malandros: Gamboa, interpretado por Oscarito, e Carvalho, por Manoel Vieira, que se encontram numa cena de rua.

Carvalho: Olá Gamboa, onde é que você vai? (aperta-Ihe a mão com violência e puxa-o).

Gamboa: Eu não vou, você é que me leva. 
Carvalho: Mas o que é que há contigo? (...)

Gamboa: Política. Cansado de passar tantas noites pregando cartazes. Até em sepultura chapei a cara do homem. Cheguei a fazer comício na porta da Central do Brasil às seis horas da tarde. E eu lá de microfone na mão (...) e meu candidato perdeu as eleições.

Carvalho: Isso acontece.

Gamboa: Mas ele garantiu que era barbada... e me disse: Gamboa, compra o que você quiser que eu pago. Nem ganhou nem pagou nada... eu comprei um colchão de molas, comprei um rádio-televisão que até agora não vi nada. Comprei tudo isso a crédito. Como é que eu vou pagar agora?

Carvalho: (...) Ô vagabundo... Aceite o meu conselho. Deixe a política. Você nunca passará de um anônimo da calçada. Teu nome nunca aparecerá nos jornais... Olha, você poderia até trabalhar comigo no meu depósito.

Gamboa: Serviço leve?

Carvalho: Serviço leve. Você sabe andar de bicicleta?

Gamboa: Sei.

Carvalho: Então irias entregar gelo em Santa Tereza.

Gamboa: Eu não chego lá. De bicicleta?

Carvalho: Você não quer nada. Olha, podias chegar a ser meu gerente. O gelo é pra tapear. Eu vivo é do câmbio negro.

Gamboa: Isso interessa. (JÚNIOR, PINTO, 1950, s.p)

Nessa dupla, percebemos dois tipos de malandragem. Gamboa deseja uma atividade que seja rentável sem exigir grandes esforços, mas é uma figura ingênua que se deixa seduzir por promessas de políticos e trambiques do amigo. Torna-se, portanto, em regra, como os palhaços, vítima das circunstâncias. CarvaIho, ao contrário, é um tipo espertalhão, desses que jogam para ganhar, flertando com certa malandragem que permeia a cidade, em negócios escusos. Na linha de pensamento de Roberto DaMatta, podem ser vistos como tipos a um passo da marginalidade e outro da estrutura, enfatizando a figura do malandro brasileiro, que é capaz de "vencer sem fazer força".

Nessa cena, como na anterior, a complementaridade dos tipos em sua "esperteza-ingenuidade" sugere aproximação com as duplas de tradições cômicas, já citadas: Maccus-Baccus, Brighela-Arlequim, Arlequim-Pierrô. Apesar dos contextos diferentes, os tipos indicam traços comportamentais que podem garantir certos mecanismos de comicidade. Por exemplo, no início da cena,quando eles 
se cumprimentam, o aperto de mão gera uma ação física cômica com o aperta e puxa.

A figura da "mulata", já tendo aparecido nas comédias de costume como mucamas sedutoras, é introduzida no teatro de revista em 1888, na revista $A R e-$ pública, de Arthur Azevedo, como a Baiana Sabina. A inspiração viria de um episódio envolvendo uma ex-escrava que vendia laranjas em frente à Escola de Medicina, localizada junto à Santa Casa de Misericórdia, ponto de encontro dos estudantes republicanos, que fizeram ali uma manifestação contra a princesa regente imperial. O episódio resultou na retirada de Sabina daquele local e numa passeata dos republicanos na qual a mulher era conduzida em posição de destaque. Era comum a mulata ser representada na revista como baiana. ${ }^{4}$

Vindo das senzalas do interior, a mulata incorporou os modismos e as gírias da cidade à sua maneira peculiar de falar, criando um linguajar específico. "As primeiras mulatas eram atrizes brancas, pintadas, e prepararam o terreno para que Otília Amorim e Araci Cortes, mulatas autênticas, impusessem um estilo próprio de interpretação" (VENEZIANO, 1991, p. 129).

Na primeira revista de Walter Pinto, É disso que eu gosto, de 1940, uma das presenças marcantes foi exatamente a da mulata Araci Cortes, uma estrela do teatro brasileiro, naquele momento. Araci cantava:

Não sou cantora nem pretendo ir pro Scala

Não sou soprano ligeiro

Porque a voz eu não emposto.

Eu sou do samba e quando é bem ritmado

Aí me espalho um bocado...

Ah!... É disso é que eu gosto!... (MARCHELLI et al., 1940, s.p)

Em 1941, na revista A cabrocha não é sopa, Araci Cortes surge numa versão de mulata grã-fina. Em cena criada a partir da música-título, a estrela contracena ao lado de Oscarito e Martins, um malandro e um português, respectivamente, que disputam o coração da cabrocha. "Araci entra com andar bamboleante, vindo em seguida Oscarito e Martins". Entra a música "A cabrocha não é sopa":

Martins: Veja que linda cabrocha/Dizem que mora no Rocha Oscarito: Tem andar bem provocante/ E usa muito pouca roupa Martins: Essa cabrocha é um perigo

Oscarito: A cabrocha não é sopa

Araci: Eu tenho corpo cheiroso, eu tenho balangandans

Quem quiser sentir meu cheiro/vá lá em casa amanhã 


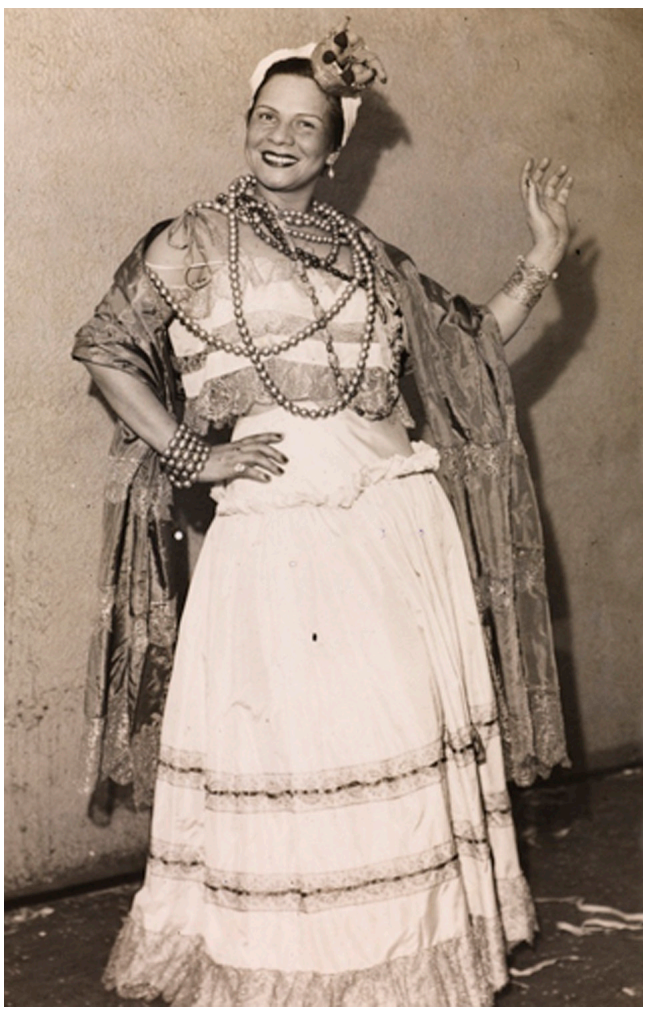

Figura 1: Araci Cortez na peça É disso que eu gosto. Arquivo Funarte

Martins e Oscarito: Mexe que mexe cabrocha/para o nosso sangue esquentar (bis)

Araci: Comigo não tem veneno, nem tombo eu vou levar

Esta cabrocha granfina eles têm que respeitar (JÚNIOR, MAIA, 1941, s.p.)

No prólogo da última revista de Walter Pinto, O diabo que a carregue lá pra casa, de 196I, Satã faz a apresentação dos ingredientes indispensáveis para se fazer uma "revista infernal" - a malícia, a luxúria, a graça e a beleza, representadas por atrizes, que entram após se ouvir uma música de carnaval.

Malícia: Carnaval! Carnaval lembra mulata!

Diabo: Claro, numa revista não pode faltar a malícia da nossa mulata...

(Entra a mulata, cantando)

Diabo: Mulata!...Tu és o oitavo dos sete pecados capitais!

Luxúria (esnobe): Já virou até artigo de exportação!

Mulata (com sotaque francês): E agorra sou artista de cinema internacional. Vou voltar pra Paris. 
Graça: Pra fazer cinema?

Mulata: Pra fazer um francesinho... vou ser mamã... já imaginou o touchê da Mulata?

Beleza: Quer dizer que você vai abandonar o cinema para ser mamã na França?

Mulata: Clarro! Pra ser artista aqui, eu prefiro ser mére de lá! (PIN-

TO, RUIz, 1961, s.p)

Nessa cena, a mulata deixou de ser a cabrocha faceira e pernóstica da favela, aprendeu a falar algumas palavras em francês e internacionalizou-se, tornando-se um símbolo nacional.

A mulata e o malandro iriam compor uma das duplas mais bem sucedidas da revista. Na peça É disso que eu gosto, há uma cena, "Dor de malandro", na qual os dois aparecem de modo ingênuo e exótico:

Malandro: Meu Deus, que felicidade/Eu te encontrá no meu caminho

Cabrocha, deixa a cidade/Vorta lá pro meu ninho (...)

Chega o que eu já sofri/Amarrota a minha cara

Mi dá uma surra de vara/ Mi pisa todo no chão (...)

Mostra que és da favela/Qui cozinhas sem panela

Qui és da farofa amarela / Da macumba e cangerê.

Cabrocha: Mulato, tu falô tanto

Qui eu já tô acomovida (...)

Vô vortá lá pra casinha/Forradinha de jorná

Vô levá um papagai/E meu violão pra tocá

Vamo juntá as mobia/ Pra vivê junto outra vez

Vô virá mão pra famia/ Não quero mais português (...)

Tu vai sê muito feliz/O pai de santo me diz

Qui tu vai se milhorá/Qui tu vai sê sorteado

Depois vai sê graduado/Até chegá maiorá.

Tu num qué sê militá?/Arrejeita, num faz má

Iscolhe o que tu quizé/Tu pode inté sê chofré

Da camabra municipá! (MARCHELL et al., 1940, s.p.)

Os tipos aparecem como representantes do morro, ainda identificados com um modo de vida bucólico e rural. Rendendo-se ao amor, abandonam as aventuras. Malandro que é ele pode "se dar bem" na carreira militar ou na repartição pública (Figura 1). 


\section{O CAIPIRA E O PORTUGUÊS}

O "caipira" é uma figura muito popular no teatro brasileiro. Foi introduzido por Martins Pena na comédia Um sertanejo na corte, de 1833, aparecendo também como o Eusébio na revista $O$ Tribofe, de Arthur Azevedo, em 1892, texto reescrito no formato de comédia em A capital federal, de 1897. O tipo foi imortalizado no cinema, como o caipira de Mazzaropi, além de fazer sucesso como as duplas de música sertaneja. A figura que se fixou na revista é a do sertanejo simples, amante da natureza, piadista e cantador de "moda de viola". Geralmente ingênuo, apresenta dificuldades de lidar com o modo de vida da cidade grande, revelando, contudo, por baixo da aparente inocência, a esperteza e a sabedoria intuitivas da gente da terra.

Na revista É disso que eu gosto, montagem de Walter Pinto, o caipira se aproxima da figura do caboclo, embutido num certo ideal ufanista, que pretende valorizar a fusão das raças (negro, índio e português) como o diferencial da identidade brasileira. Ele é enaltecido no choro "O meu cabôco", em contraste com o malandro, por seu jeito "politicamente correto" de levar a vida. É uma atriz quem canta:

Todas muié/ Tem idea na vida,

Tem seus amô, tem suas pretensão.

Desde as sincera inté as mais fingida.

Escóie um home e dá seu coração.

Por essas pestes a gente fica louca,

E troca tudo que ha nesse mundo. (...)

Eu arranjei um caboquinho bem facero

Qui é pra mim o maió dos brasileiro.

Não é dotô, nem divogado nem tão pouco bacharé.

Não tem anné e nem é coroné.

É inducado e pelos modo todo mundo vê

Qui o meu amô é patriota cumo que.

Serve o Brasil de um modo todo ispiciá.

Esse cabôco é...é... é Fuzilêro Navá! (MARCHeLlu et al., 1940, s.p.)

Há, nessa cena, a identificação do caipira com o fuzileiro naval, agente ingênuo do ideal nacionalista e das forças da Marinha que atuaram na campanha brasileira durante a Segunda Guerra Mundial.

Nas peças de Walter Pinto, o caipira é representado quase sempre como figura folclórica, diferente de sua marca contextual no teatro dos primeiros decênios. Em vez de aparecer na oposição entre homem do campo e homem da cida- 
de, como nas revistas de Arthur Azevedo, o tipo simplório aparece próximo a outras figuras da periferia da cidade, como o morador do morro ou o trabalhador explorado, provável reflexo das transformações urbanas. Configura-se aí o embate entre o grã-fino e o suburbano ou o pequeno-burguês e o homem do povo.

O quarto tipo apresentado por Neyde Veneziano é o "português", presente no anedotário popular como uma figura de pouca inteligência. Caracterizado pelo sotaque, por grossos bigodes e tamancos, ganhou destaque em O Bilontra, de Arthur Azevedo, peça de 1886. O tipo teria surgido de um episódio envolvendo um comerciante português que vivia no Brasil e comprara um título de nobreza falso, comemorado com uma grande festa, transformando-se em piada nacional. Rir da figura do português fortalecia o sentimento nacionalista do país, recém-independente. Com a piada, o brasileiro "carnavalizava" o sentimento de colonizado.

Na revista $A$ cabrocha não é sopa, de $194 \mathrm{l}$, o português aparece no quadro "Vingança Tardia".

(Entra Manoel espancando Moisés, que grita por socorro)

Manoel: Pode gritar à vontade, seu covarde. Eu sou homem. Comigo não.

Moisés: (gritando) Socorro! Socorro! Eu não fiz nada. O senhor está me espancando e eu sou inocente.

Guarda: (entra correndo) O senhor não pode espancar um homem dessa maneira.

Manoel: O senhor sabe quem é este homem, seu guarda? É Moisés!

Guarda: Mas o que tem isso?

Manoel: Então o senhor não sabe o que ele fez a Jesus Cristo?

Guarda: Ora. Mas isso já foi há dois mil anos.

Manoel: Ah, sim. Mas eu só soube ontem... (JÚNIOR, MAIA, 1941, s.p)

Nessa peça, como vimos em cena já citada, o português disputa o amor da mulata com o malandro, situação muito comum no teatro de revista.

\section{O CARIOCA E A MULHER FATAL}

Um amplo painel de tipos populares pode ser composto pelo estudo das revistas de Walter Pinto, destacando-se figuras cômicas e personagens anônimas, recolhidas no cotidiano da cidade. Flora Süssekind (1986) indica dois tipos recorrentes na revista: "o carioca" e a "a mulher fatal". 
O típico "cidadão carioca", normalmente costuma ser confundido com a figura do malandro. Seu aspecto irreverente, alegre e sedutor, sua relação com o mundo do samba e do futebol, sem dúvida, aproximam-no bastante do malandro. Da revista $A$ cabrocha não é sopa, recortamos uma cena que tenta desvincular os dois tipos, resgatando o perfil do carioca como um homem do povo que sabe equilibrar o trabalho e os deveres com sua vocação para o prazer. A homenagem é cantada por uma atriz na música "O carioca".

Ele trabalha de segunda a sábado

Com muito gosto sem reclamar

Mas no domingo ele tira o macacão

Embandeira o barracão

Põe a família pra sambar

Com ele ninguém se mete

Lá no morro ele pinta o sete

Ali ninguém é fingido

Ganha-se pouco mas é divertido.

Ele nasceu sambista

Tem a tal veia de artista

Carteira de reservista

Está legal com o senhorio

Não pode ouvir pandeiro

Fica cheio de dengo

É torcida do Flamengo

É do Rio de Janeiro (JUNIOR, MAIA, 1941, s.p)

Esse perfil de bom moço do carioca pode estar relacionado à moralização proposta pelo Estado Novo, através de seu Departamento de Imprensa e Propaganda - DIP, que, naquele período de conotação desenvolvimentista, valorizava a figura do cidadão sério e trabalhador, desestimulando (e censurando) as representações identificadas com a malandragem.

Sem ser exatamente um tipo fixo, a "mulher fatal" é uma presença imperiosa, é a alegoria, a personificação do próprio gênero, sem a qual a revista não teria graça. A mulher, encarnada na malícia que encobre e descobre o corpo no jogo dos duplos sentidos, iria conferir alma e movimento à cena. Desse modo, a revisão crítica e satírica dos fatos jamais ganharia um enfoque solene e tenso, contaminando-se pelo ardor e sensualidade da mulher e pelo ritmo quente do samba, metamorfoseando a realidade em festa para os sentidos. 
Roberto DaMatta (1977, p. 147) discute a presença das "fantasias femininas" no carnaval, caracterizando-as por dois grupos específicos. O primeiro constrói a imagem de uma mulher ideal, recatada, serena, frágil, sendo representada como bailarina, borboleta, jardineira e pastora. A mulher borboleta ou bailarina conjuga beleza com leveza, pureza e arte. A jardineira e a pastora cuidam delicadamente das plantas e dos animais e estão confinadas ao mundo doméstico, tendo sua sexualidade controlada e a serviço dos homens (pai ou marido). Fantasias de carnaval retratando a mulher como supermãe, grávida ou "patroa" são bastante utilizadas por travestis e representam uma sátira masculina à rotina doméstica feminina e uma crítica ao caráter manipulador da mulher no âmbito do lar. Ao transformá-la em mero clichê, está implícita também uma desvalorização de suas atividades.

O segundo grupo de fantasias, o das vedetes, melindrosas e empregadas, cria outro tipo de caracterização da mulher, remetendo-a, indisfarçadamente, à idealização como objeto sexual. Para o pesquisador, a mulher passa a ser vista como um ser provocante e agressivo: "Não é mais uma imagem bucólica ou pastoral, mas uma visão sensual do feminino nos seus aspectos mais agressivos e incontrolados. É uma imagem centrada na sexualidade feminina, tomada como um instrumento de obtenção de admiração, prestígio e poder". Nas inversões típicas do carnaval, nos salões de baile as mulheres dançam seminuas sobre as mesas, e os homens sentem-se envaidecidos em mostrá-las aos outros. "São as mulheres que passam abertamente a comandar o espetáculo, pois o 'Rei Momo' é gordo e representa uma figura onde a gula substituiu o sexo, mas a 'Rainha do Carnaval' é sempre uma vedete de formas perfeitas" (DAMATTA, 1977, p. 139).

É exatamente como a vedete que a "mulher fatal" alcançaria os mais altos píncaros da glória no espetáculo de revista. Os corpos das coristas emolduravam todo o espetáculo, mas o ponto culminante era aquele em que surgia, do alto de uma escadaria, sob as luzes e acordes da orquestra, a figura deslumbrante da vedete.

No imaginário desse teatro, surpreende o relato da atriz Mara Rúbia sobre sua ascensão ao estrelato. A atriz havia chegado com dois filhos ao Rio de Janeiro, vindo de sua terra, a Ilha de Marajó, após ter-se separado do marido, um político do Pará. Em 1944, procurou a Companhia Walter Pinto, que publicara um anúncio no Jornal do Brasil convidando moças para fazer testes como girls. Mara Rúbia entrou na revista Momo na China ${ }^{5}$ e em três meses se tornaria a estrela da companhia. Vejamos um trecho de sua entrevista concedida ao Serviço Nacional de Teatro. 
Mara Rúbia: Nessa primeira revista eu fiquei entre girl e, digamos assim, a soubrette para chegar então a vedeta... para chegar a estrela; então era assim uma espécie de hierarquia que havia. A estrela era uma coisa, a vedeta era outra, a soubrette era outra.

Maksen Luiz: O que é a soubrette?

Mara Rúbia: A soubrette é aquela que faz uma zombadinha para ganhar tempo e ter tempo; é bonitinha só.

Nélia Paula: Ela é um enfeite, né?

Mara Rúbia: É uma coisa mais decorativa, mas que já canta e dança um pouquinho, mas não está fazendo nada; só enfeitando. (...) $\mathrm{E}$ quem chegava a ser vedeta numa peça de Walter Pinto já era o máximo. E eu já não era vedeta, era estrela... A vedeta é quando você começou, chegou mais uma... tinha outras antes de mim; (...) mas a estrela é aquela que as cadeiras rangem quando ela entra, como sempre dizia o Walter... Então eu ficava escutando se rangia: rangia.... Então eu sou uma estrela!... Até que eu cheguei realmente a comandar o espetáculo (RÚBIA, 1977, p.122-127).

O "número de plateia" era o momento culminante da estrela. Ela descia por uma passarela que avançava para a área do público, deixando suspensa a respiração dos homens pelo alcance das deusas. Virgínia Lane era mestra em número de plateia. Na revista Está com tudo e não está prosa, de 1949, fazia uma cena musical maliciosa que ganhou fama. Título: "Vendedora de amendoim".

Vá por $\mathrm{mim} /$ prove o meu amendoim

Pois atesta todo mundo/ Que levanta/ Num minuto um moribundo.

Teve um insulto um cavalheiro/Que tristeza/ Que ficou com a língua presa

Já não dava uma palavra, quase mudo

Para falar ele fez tudo/ Apelou depois pra mim/ Dei-lhe o meu amendoim

Logo após a sorrir/ Ele deu uma, deu duas/ Três palavras a seguir.

(vai à plateia e oferece graciosamente a mercadoria a um espectador).

Não tenha acanhamento, cavalheiro. É só uma amostra... Se não tem dente, dou-Ihe gingilin. Faz o mesmo efeito... Não é tapeação. Trago aqui alguns atestados que passo a ler (lendo).

- Esplêndido. Maravilhoso o seu produto. Efeito rápido. (Luiz Iglésias, Luiz Peixoto, Gastão Tojeiro) 
- Maravilha! Impressionante. Lamento não o ter experimentado antes de ir para Paris. (Walter Pinto)

- Foi tal o efeito que ofendi o decoro parlamentar e perdi o mandato. (Barreto Pinto)

- Foi tal o efeito que consegui manter a dita/ dura durante 15 anos.

(Getúlio Vargas) (JúNIOR, PINTO, 1949, s.p)

No final da cena de Virgínia Lane, referência ao romance que diziam ter a atriz com o presidente Getúlio Vargas, fato ou boato que ela alimentou ao longo de sua trajetória.

Na revista $O$ diabo que a carregue lá pra casa, na cena já citada, o diabo apresenta sua receita de uma revista infernal, com os elementos encarnados por tipos diferentes de mulheres, reunidas num coro que diz:

Se a mulher é tentação/ E Satã foi quem a fez

Pobre homem vai pecar/ Trinta dias cada mês .

Vive o homem a pensar/ Só na beleza que ele quer

Essa coisa vou dizer/ É isso mesmo: mulher!

Só quer, e só quer é pensar em mulher!

Só quer, e só quer, beijar a mulher/ é amar a mulher! (PINTO, RUIZ, 1961 , s.d)

Entra em cena o diabo que apresenta o ingrediente final que despertará nos homens o pecado da luxúria: "Com vocês: a rainha do teatro de 62". Entra Íris Bruzzi:

Vedete: (canta) É sensual/ escultural/ De beleza provocante.

Coro: A vedete!

Vedete: $\mathrm{E}$ tem mais que ninguém/ a malícia mais picante.

Coro: A vedete!

Vedete: Com voz quente a cantar/ fogueira no olhar

Que diz o que quer...

Ser mulher... Bem mulher!

E ter sedução que tenta/ Prende, prende quantos quer! (PINTO, RUIZ, 1961, s.d)

Nesse número musical, a vedete enaltece a própria beleza valorizandose como um monumento alegórico. Essa idealização projeta uma mulher-objeto, quase um monstro sagrado inatingível em sua forma escultural.

Com o esvaziamento da revista enquanto gênero de revisão e crítica da atualidade, permaneceu a vedete, suporte para a fantasia e a manutenção de um público que começava a se esgotar. Fantasia que se realizava, às vezes, por inver- 


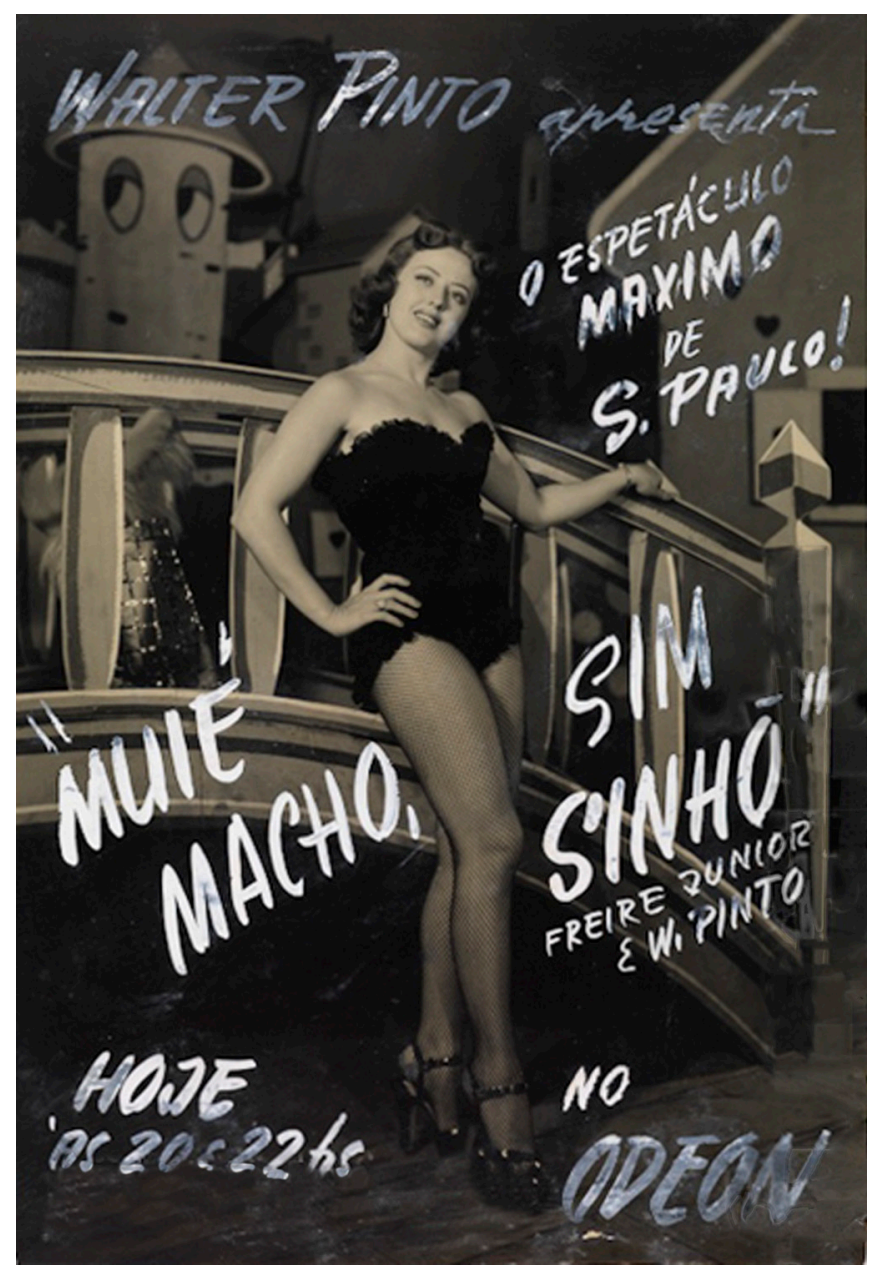

Figura 2: Virgínia Lane, no cartaz de publicidade da peça Muié macho sim sinhô. Foto Arquivo Funarte

sões e simulacros, já que, ao lado da exploração da imagem feminina e de sua nudez, surgia em cena o travesti, provocando ambiguidade em torno dos objetos do desejo.

\section{FIGURAÇÕES E ESFACELAMENTOS: ALEGORIAS, TIPO E TOPO}

Ganhando corpo entre a fantasia e a realidade, a revista de Walter Pinto sobreviveu até a década de 1960. Em Muié macho sim sinhô, de 1950 (Figura 2), no quadro "No reino da fantasia", duas personagens alegóricas, a Fantasia e a Realidade disputam a companhia de Júlio Verne. No meio desse debate, outras personagens desfilam representando as fantasias da época como o Cadillac, a Miss 


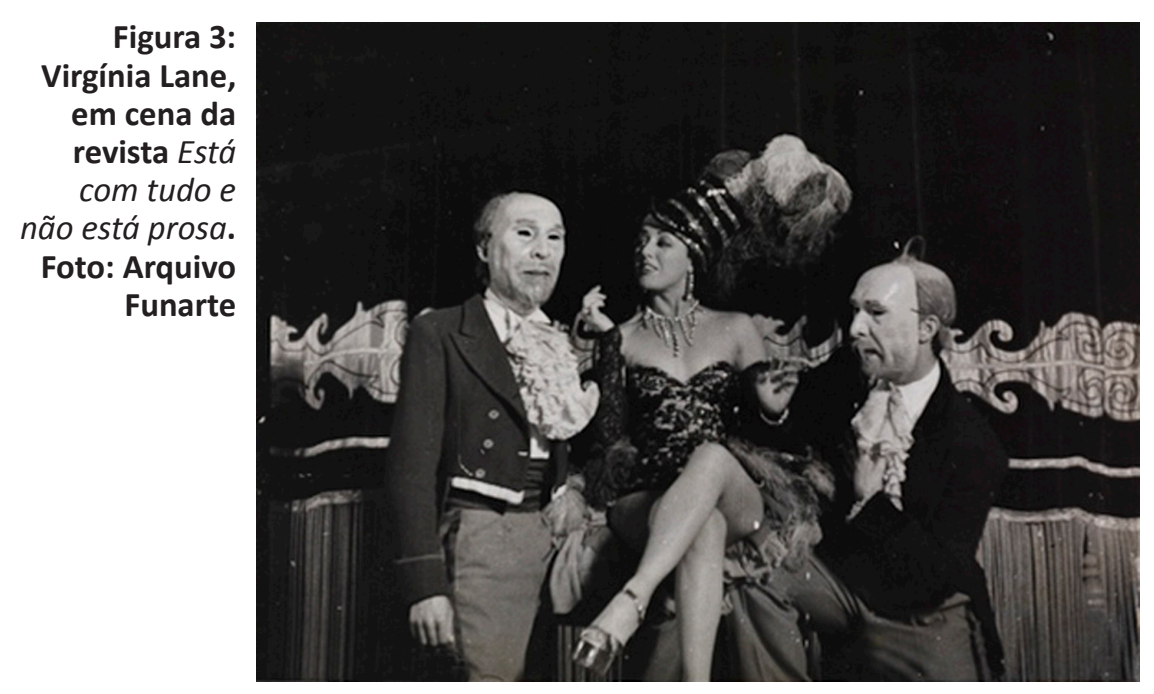

Portugal, a rumba, a roleta e a paz. Ponto culminante é a entrada triunfante da própria figura da "Revista" na presença provocadora de Virgínia Lane (Figura 2):

Realidade: Agora sim! Agora você saiu do reino da fantasia e está na realidade diante do público. Toca pra frente e mostra que a revista é Muié macho sim sinhô!

Revista: (cantando):

O teatro é um sonho entre flores

É o recreio dos nossos corações

Oficina de luz e de cores

De romance, alegria e emoção.

Somos fortes e unidos lutamos

Pelo nobre e sublime ideal

De manter no Brasil que adoramos

A eterna glória do Teatro Nacional.

Companhia Walter Pinto

Sempre foste e serás a primeira

Conquistando a alma e o coração

Da querida plateia brasileira.

É meu! É seu! Recreio! (JÚNIOR, PINTO, 1950, s.p)

A própria revista enquanto gênero surge como síntese alegórica, justaposição entre a crônica dos acontecimentos da realidade e a fantasia cênica. Um manifesto de resistência enaltece o Teatro Recreio como desejo de construção de uma identidade para o teatro brasileiro. Sem dúvida a revista se tornaria uma ma- 
triz importante na trajetória das formas teatrais brasileiras, gênero sempre reeditado de algum modo pelos musicais, mas que, nos anos 50, ante a dificuldade de se reinventar, caminhava para o esfacelamento.

Umberto Eco (1987) vê as "personagens-tipo" como resultado de uma ação representada de modo convincente, podendo ser consideradas de forma artística por sintetizarem os problemas gerais de seu tempo, mesmo os mais abstratos, tornando-se figuras emblemáticas e modelares. Em sua opinião, o tipo pode assumir uma função simbólica, quando as pessoas das mais diversas situações sociais e experiências de vida nela se reconhecem. No entanto, diferencia-se do símbolo porque este preexiste à obra, como elemento de um repertório mitológico ou antropológico, enquanto o tipo nunca preexiste à obra, constituindo-se num resultado, uma vez que se realiza a partir das conjunções da ação e da situação dramática, num processo de atualização. Alguns tipos podem ser mais bem definidos como topos - topoi, tópicos - elementos fáceis de convencionalizar, úteis e inocentes, como observa Umberto Eco $(1987,232)$ :

Eles nos socorrem como módulos imaginativos que se consomem na impressão não aprofundada, e seu emprego tem algo de felicidade inventiva com a qual de um lampejo de vida se extrai uma situação narrativa. (...) O topos é aplicado nos momentos em que certa experiência exige de nós uma solução inventiva, e a figura evocada pela lembrança substitui exatamente um ato compositivo da imaginação, que, pescando no repertório do já feito, se exime de inventar aquela figura ou aquela situação que a intensidade da experiência postulava.

Nessa perspectiva, o topos funciona como uma citação, um elemento cambiável de um jogo que pode ser transformado em outra coisa. Geralmente está relacionado a uma estrutura pré-modelada e fixada, traduzindo posturas conservadoras, como é o caso da revista em quadrinhos, literatura policial e das personagens televisivas. Ocorre, porém, desenvolve Umberto Eco, que certos topos convencionais conseguem ultrapassar a citação esquemática, podendo revelar a forma orgânica e profunda de um tipo, tornando-se modelo de uma situação concreta. Nesses casos, o tipo torna-se um elemento de tensão na estrutura narrativa, renovando-se à medida que participa da construção de um novo modo de narrar.

Na revista de Walter Pinto os tipos aparecem de modo bastante flexível, relacionados aos costumes de carnaval, como citação de personagens da literatura e da comédia clássica, e como ressonância dos tipos cômicos tradicionais. Configuram-se elementos dispersos na cultura que, de algum modo, conseguiram representar tipos da atualidade e atitudes psicológicas e sociais, daquele período 
de modernização da sociedade. É possível identificar uma estrutura de tipificação das tradições populares no universo da revista de Walter Pinto e fazer relações com o contexto representado na cena, mas os tipos se tornariam aos poucos figuras meramente esquemáticas e objetos de citação. No exame de boa parte das revistas de Walter Pinto, deparamo-nos com representações alegóricas fragmentadas. As imagens aparecem dissociadas nos textos, sugerindo uma coleção de referências em que não há preocupação em construir unidade estética ou ideológica. Citações perdidas no tempo e no espaço trabalham em função de uma "referencialidade" óbvia, travestidas de fantasia e de exotismo.

É certo que não podemos considerar a revista a configuração de tipos orgânicos, passíveis de representação alegórica, como diz Umberto Eco, ou uma síntese social perfeita, como propôs DaMatta. As últimas revistas de Walter Pinto apresentavam um universo esvaziado de conteúdo social, recheado de figuras repetitivas. Ainda assim, parece-nos uma atitude apaixonada, tentativa de manter viva uma tradição teatral popular, às vésperas da disseminação dos meios tecnológicos e do domínio da televisão como veículo de informação e de diversão popular.

\section{NOTAS}

10 presente texto recorta e aprofunda alguns estudos iniciados durante a participação da autora na pesquisa integrada Funarte/CNPq, intitulada Teatro de Revista: Estado, política e cultura, sob a coordenação do professor doutor Victor Hugo Adler Pereira (Uerj), realizada de 1994 a 1996. A autora apresentou como resultado final a monografia: A personagem-tipo: tradição e representação na revista de Walter Pinto.

2 Perspectiva estruturalista proposta por Victor Turner (1974), que estuda a organização social de um povo através de duas categorias antropológicas: estrutura e communitas.

3 Todas as peças citadas ao longo deste trabalho foram pesquisadas no Arquivo Walter Pinto, no Centro de Documentação da Funarte. Os textos encontramse mimeografados. Todas as cenas de peças citadas encontram-se sem numeração de página.

4 A baiana da revista Bendengó, de Oscar Pederneiras e Figueiredo Coimbra, de 1989, e a mulata de Forrobodó, de Luís Peixoto e Carlos Bittencourt, de I9II, ajudaram a fixar o tipo na revista brasileira.

5 Peixoto, Luiz; Bôscoli, Geysa. Momo na Fila. 1944. 


\section{REFERÊNCIAS BIBLIOGRÁFICAS}

ARISTÓTELES. Arte retórica e arte poética. Trad. Antônio Pinto de Carvalho. Rio de Janeiro: Ediouro. S.d.

COSTA, Victor; FAISSAL, Floriano; PINTO, Álvaro. Acredite se quiser: revista fantasia em dois atos e 23 quadros. Rio de Janeiro: Arquivo Walter Pinto, Centro de Documentação da Funarte. 1940.

DAMATTA, Roberto. O carnaval como rito de passagem. In Ensaios de antropologia estrutural. Petrópolis: Vozes, 1977.

ECO, Umberto. Apocalípticos e integrados. Trad. Pérola de Carvalho. São Paulo: Perspectiva, 1987.

GASSNER, John. Mestres do teatro I. Trad. Alberto Guzik e J. Guinsburg. São Paulo: Perspectiva, 1991.

JACOBI, Rugero. A expressão dramática. Rio de Janeiro: INL, 1956.

JÚNIOR, Freire; MAIA, J. A cabrocha não é sopa. Rio de Janeiro: Arquivo Walter Pinto, Centro de Documentação da Funarte, 1941.

JÚNIOR, Freire; PINTO, Walter. Muié macho sim sinhô: revista em dois atos. Rio de Janeiro: Arquivo Walter Pinto, Centro de Documentação da Funarte, 1950.

MARCHELLI, Vicente; OSCARITO; BRENNIER; ORRICO, Miguel. É disso que eu gosto: revista charge em dois atos e 21 quadros. Rio de Janeiro: Arquivo Walter Pinto, Centro de Documentação da Funarte, 1940.

ORTIZ, Renato. A moderna tradição brasileira: cultura brasileira e indústria cultural. São Paulo: Brasiliense, 1988.

PINTO, Walter; RUIZ, Roberto. O diabo que a carregue lá pra casa: revista em dois atos. Rio de Janeiro: Arquivo Walter Pinto, Centro de Documentação da Funarte, 1961.

SÜSSEKIND, Flora. As revistas de ano e a invenção do Rio de Janeiro. Rio de Janeiro: Nova Fronteira/Fundação Casa de Rui Barbosa, 1986.

TURNER, Victor. O processo ritual. Petrópolis: Vozes, 1974, p.116-159.

VENEZIANO, Neyde. O teatro de revista no Brasil: dramaturgia e convenções. Campinas: Editora da Universidade Estadual de Campinas, 1991.

Nanci de Freitas é professora adjunta no Instituto de Artes, da Universidade do Estado do Rio de Janeiro e doutora em teatro pelo Programa de Pós-Graduação em Artes Cênicas, da UNIRIO. Atua na área de artes cênicas como atriz, diretora e pesquisadora, coordenando, na Uerj, o projeto Mirateatro! Espaço de estudos e criação cênica e o Laboratório de Artes Cênicas.

Recebido em: 04/04/2015

Aceito em: 02/05/2015 